\title{
The Healthy School Approach: Different Perspectives of Students and Educators
}

\author{
Marie-Claude Rivard ${ }^{1} \&$ Rollande Deslandes ${ }^{2}$ \\ ${ }^{1}$ Department of Physical Activity Sciences, Universite du Quebec a Trois-Rivieres, Trois-Rivieres, Canada \\ ${ }^{2}$ Department of Education Sciences, Universite du Quebec a Trois-Rivieres, Trois-Rivieres, Canada \\ Correspondence: Marie-Claude Rivard, Department of Physical Activity Sciences, Universite du Quebec a \\ Trois-Rivieres. E-mail: marie-claude.rivard@uqtr.ca
}

$\begin{array}{ll}\text { Received: February 19, } 2014 & \text { Accepted: April 9, } 2014 \quad \text { Online Published: May 14, } 2014 \\ \text { doi:10.5539/jel.v3n2p135 } & \text { URL: http://dx.doi.org/10.5539/jel.v3n2p135 }\end{array}$

\begin{abstract}
The issue of health occupies a central place in the official texts on education. In Quebec, the Healthy School Approach (HSA), situated at the crossroads of education and health, stands out for its comprehensive and integrated health promotion in schools. This qualitative study aims to describe the perceptions and involvement of 19 participants (students and educators) on health issues within the context of the HSA in a low socioeconomic school in Quebec. The use of focus groups revealed that the participants interviewed generally associate health with lifestyle, particularly physical activity and nutrition, while the educators demonstrate their involvement in a differentiated manner. The importance of a shared vision of health among students and educators in the pursuit of concerted and complementary health education in disadvantaged environments is highlighted.
\end{abstract}

Keywords: health education, lifestyle, perceptions, involvement, students, educators

\section{Literature Review}

\subsection{Context}

The adoption of the Ottawa Charter followed by the Jakarta Declaration (World Health Organization, 1986, 1997) served as a lever for integrating the issue of health into official texts on education (Puhse \& Gerber, 2005). The term health education refers to health-related objectives implemented in schools.

In Quebec, the work on the Estates General in Education made health education an official subject area throughout the school network (Ministry of Education for Quebec [MEQ], 1997). Since then, this educational drive to empower students in terms of healthy lifestyle choices has led to the reform of the school curricula (MEQ, 2001, 2004). The Quebec curriculum includes three strategies for health education. The first concerns physical education and health (PEH), particularly the competency of adopting a healthy, active lifestyle. Writings on the subject indicate that this disciplinary competency presents a challenge to PEH teachers, as the addition of the health component calls for expanding prior teaching contents and practices (Rivard, Porlier, \& Collet, 2009; Turcotte, Gaudreau, \& Otis, 2007). To meet the challenge, Otis (2009) suggests deploying health education in collaboration with other actors in the school and thus legitimizes the second strategy, which is the key education theme, Health and well-being. Because a key education theme depends on the structuring of collective actions and the integration of multidisciplinary knowledge, it offers an ideal opportunity for involving all members of the school staff in the development of health-related educational projects. Finally, the third strategy concerns Complementary educational services, particularly the Promotion and prevention services (MEQ, 2002), which are aimed, precisely, at the student's health and well-being. Despite these guidelines for promoting school health, however, it often happens that no one assumes official responsibility for it, and its value and scope are therefore limited (Otis \& Grenier, 2010).

\subsection{School Health Initiatives}

An increasingly prolific international literature discusses the health-related initiatives implemented in schools. The "Healthy School" concept became widespread beginning in the 1980s and appears in the literature under various headings, as networks like the "European Network of Health Promoting Schools" and the "Swiss Network of Health Promoting Schools" or programs like the "Comprehensive School Health Programs" in the United States or the "Health Promoting Schools" in Australia. Researches on the subject agree on a certain 
number of obstacles related, especially, to implementation. Examples include the role of teachers, deemed to be essential and particularly challenging in the planning and animation of health education activities; the different perceptions of students, parents, and school staff regarding school health; and partnership with the community, which requires a sharing of responsibilities viewed as complex because of the many layers of stakeholders involved (e.g., Baltasar, Feller-Lânzlinger, Furrer, \& Biebricher, 2007; Beaudoin, 2011; Deschesnes, Martin, \& Jomphe-Hill, 2003; Lynagh, Perkins, \& Scholfield, 2002; Rissel \& Rowling, 2000; St Leger \& Nutbeam, 2000).

\subsection{A Shared Responsibility}

For this reason school health initiatives present numerous challenges, notably regarding the lack of collaboration and a shared vision among the various actors (Deschesnes et al., 2008; Rivard, Deslandes, \& Beaudoin, 2011). In Quebec, the Healthy School Approach situated at the intersection of health and education is noteworthy for its global and integrated promotion of school health (Martin \& Arcand, 2005). Indeed, the approach calls for a renewed collaboration among those involved in its deployment, and the few existing studies of the issue show a strong receptivity on the part of stakeholders in the educational community in this regard (Deschesnes et al., 2008). According to the Canadian writings mentioned by Beaudoin (2011), the key to implementing this type of global, concerted approach in schools is collaboration by all the actors. Among the latter, the school staff or educators play a decisive role for several reasons: they interact with students on a day-to-day basis, have credibility with the students, and possess competencies developed during their training and teaching experiences (Jourdan, 2010). Students are key actors as well in that, besides being the target of these school health initiatives, they are also directly called upon to assume responsibility for a healthy and active lifestyle (Martin \& Arcand, 2005; MEQ, 2001, 2004). Loizon (2009) goes farther by pointing out that students must feel that the knowledge they gain from health education is coherent and meaningful to them in their day-to-day life.

To our knowledge, no research has yet been done on students' opinion of the place of health in their disadvantaged schools. The particular context of health in low socioeconomic areas, however, is as much a concern (Deniger, Abdoulaye, Dubé, \& Goulet, 2009; Harris \& Goodall, 2007) as health in the larger sense of the word. With regard to lifestyles, Canadian studies indicate that a family's socioeconomic situation is one of the strongest predictors of physical activity in young people (Mo, Turner, Krewski, \& Mo, 2005). The recent review of the literature by Stalsberg and Pedersen (2010) supports the hypothesis that adolescents from disadvantaged environments are more active. Other studies have focused on social skills in terms of conflicts and the eruptions of violence that tend to occur in schoolyards, especially in low-income areas (Dionne, Lavoie, Morency, \& Paradis, 2009). In Quebec, the Agir autrement intervention strategy is a key method for preventing violence in such environments (Ministry of Education, Leisure and Sport [MELS], 2009).

\subsection{Conceptual Frameworks}

Our study therefore focuses on two groups - students and educators - who can elucidate their separate opinions of the Healthy School Approach in terms of perceptions and involvement. Perceptions guide individual interactions in a certain fashion, and these interactions, in turn, mirror the various actions of involvement (Larose, Lenoir, \& Karsenti, 2002). There are, as far as we know, no studies of these two variables of the Healthy School Approach in low-income environments. Two models were retained as theoretical anchors to document perceptions and involvement and provide links between the objectives, the methodological choices and the elements of the discussion.

\subsubsection{Healthy School Approach Model}

This model is rooted in ecosystemic theories postulating that the child is influenced by the multiple environments in which he/she lives (Bronfenbrenner, 1986). Employed in Quebec schools since 2005, the Healthy School Approach (HSA) has a threefold objective: school success, young people's health and well-being, and the aims of the Québec Education Program (MEQ, 2001). The approach is considered innovative in that it is based on a dual conception: It is global insofar as it groups together the key factors of young people's development regarding both the individual (self-esteem, social skills, safe and healthy lifestyles and behaviours in sports-related travel and practices) and the environment (school, family, community and preventive services); and it is concerted because the actions are conducted on different levels by different actors - the students, the school, the family and the community, which consists of stakeholders in the environment who are influential in terms of employing the approach (Martin \& Arcand, 2005). Since the present study examines the perceptions of students and educators in the Healthy School Approach, we believe we are correct in linking these perceptions to the variables of this model. 


\subsubsection{Educators' Participation Model}

The second model, that of Hoover-Dempsey et al. (2010), stipulates that the involvement of parents, applicable to educators as well, influences the student's grades and behaviours. This model is well suited for examining the involvement of these adults as regards young people's health and offers four types of action: modeling, reinforcement, teaching and encouragement. When young people are exposed to the good example of models, they acquire skills and competencies (Bandura, 1997). The more they see models (for example, educators) as forceful and competent, the greater the influence on their behaviours and attitudes. Reinforcement is associated with the theory of behaviour shaped by consequences (Skinner, 1989). This theory of reinforcement predicts that young people are more likely to adopt behaviours in response to reward. In other words, the participation of educators via reinforcement influences school success and the adoption of healthy lifestyles. Teaching, in the sense of instruction, refers to the action of communicating knowledge which, in turn, influences targeted results. Open or interactive teaching appears to foster a greater autonomy and reasoning capacity than does directive or authoritarian teaching. Finally, encouragement corresponds to the implementation of strategies and methods conducive to stimulating young people's motivation to adopt desired behaviours.

\subsection{Objectives of the Study}

The two groups of participants in the study were questioned concerning perceptions and involvement. The objectives aim to: 1) describe the perceptions of students and educators regarding school health, and 2) examine involvement based on the educators' actions to promote health as perceived by both groups.

\section{Method}

\subsection{Environment and Participants}

In keeping with the study by Yin (2003), we chose a school with the optimal conditions for achieving our research objectives. The targeted school was recognized as a leader in its community based on the following criteria: HSA in effect for about six years; openness to, and collaboration on, research projects; mobilization of educators; combined aims of achievement and success rooted in the school's success plan; and a committee for monitoring success. About 240 students from grades 1 to 6 from urban and semi-urban environments attend the targeted school. The school is involved in the Agir autrement intervention strategy and is rated $9 / 10$ on the socioeconomic environment index (EEI) as calculated by the Ministry (MEQ, 2003) (Note 1). Table 1 presents the two categories of participants who took part in the study. Based on qualitative research that seeks to understand and explain the point of view of participants, we used a non-probalistic and intentional sample aiming at selecting information-rich participants that are representative of other actors in their environments (Merriam, 1998). In the study, an invitation was launched to educators attending a staff meeting. The educators that were chosen accepted to participate on a voluntary basis and they came from one of the targeted intervention school sectors, namely, physical education specialist, psychoeducator, educational technician and daycare supervisor. As for the students, they were recruited by their classroom teacher and selected in function of the learning cycle ( $2^{\text {nd }}$ cycle, 9-10 years and $3^{\text {rd }}$ cycle, 11-12 years) and according to the following criteria : leaders or committee members in their class or in their school, average or above average academic performance and gender representativeness. We thus made sure that the respondents were well knowledgeable of the topic and that their voice was credible in their group or in their school.

Table 1. Two categories of participants

\begin{tabular}{ll}
\hline Students $(\mathrm{n}=12)$ & Educators $(\mathrm{n}=7)$ \\
\hline $2^{\text {nd }}$ cycle $(\mathrm{F}=4, \mathrm{H}=2)$ & Physical Education specialist $(\mathrm{H}=1)$ \\
$3^{\text {rd }}$ cycle $(\mathrm{F}=3, \mathrm{H}=3)$ & General teachers $(\mathrm{F}=3)$ \\
& Technician $(\mathrm{H}=1)$ \\
& Psychoeducator $(\mathrm{F}=1)$ \\
& Daycare supervisor $(\mathrm{F}=1)$ \\
\hline
\end{tabular}




\subsection{Tool}

The method retained for achieving our objectives was the semi-directed focus group, because the interrogation method offers flexibility and generates a wealth of data that can lead the discussion into different avenues (Geoffrion, 2003). As well, it has the advantage of obtaining participants' personal viewpoints while creating a group dynamic that inspires the expression of new statements (Geoffrion, 2003), shared ideas, and nuance (Bogdan \& Biklen, 1992; Patton, 2002), which is helpful when dealing with young people. Three distinct focus groups composed of 19 participants in all were conducted, two with six students each, and one with seven educators. The focus groups took place in the school; they lasted about 60 minutes for the educators and 30 minutes for the students. A special grid adapted to the group of participants was developed based on two conceptual frameworks and the recent literature on the subject. Finally, after content validity was established with a sample resembling the participants in the study, we divided the interview grid into six sections, two of which are the focus of this article. Each group was questioned as follows: School health: Students/Educators: In your opinion, is school X a healthy school? Why? Educators' involvement: Students: At school, what actions do your teachers take that convince you they consider your health important? Educators: As educators, what actions do you take to empower your students in terms of their health?

\subsection{Analysis Strategy}

The qualitative data were analyzed using L'Écuyer's mixed content analysis (1990). The procedure consisted in drawing on predetermined categories in the literature: the Healthy School Approach model (Martin \& Arcand; 2005 ) in reference to objective \#1 (perceptions) and the educators' participation model (Hoover-Dempsey et al., 2010) in reference to objective \#2 (involvement). It also made room for the appearance of new categories as needed. The NVivo software allowed for work on the breakdown, coding and regrouping of units of meaning, the emergence of typologies and an analysis of similarities and differences between the study's participants.

\section{Findings}

In keeping with the first objective, which is to describe the perceptions of the actors (students and educators) as regards school health, the following overview presents only the lifestyle-related variables underscored during discussions. These include, in particular, physical activity and nutrition, safe and healthy behaviours related to travel and sports practices, and social skills (Martin \& Arcand, 2005).

\subsection{Perception of School Health}

\subsubsection{Students' Perspective}

To begin, cycle 2 students consider school $\mathrm{X}$ to be a healthy school. The main reasons given concern the rules governing nutrition: "We don't have the right to bring candy to school" and the sense of safety conferred by the many resources and the continued supervision in the area: "When cars are going fast, there's always a crossing guard to help us cross" or "We don't have the right to fight in school, and that means it's safe." This group also discusses the place of sports in school: "They [the teachers] make us do a lot of sports...they give us more phys ed [physical education], sometimes they even give us whole afternoons of phys ed."

The older group of students in cycle 3 also stress nutrition, but reveal a special concern with safety by mentioning multiple examples such as the organization of games during schoolyard recess: "They separated the activities because there was too much fighting." They also indicate the intervention, as needed, by specialists such as technicians in special education. Students in this group likewise point out the necessity for safety equipment such as bike helmets and behaviour management policies like bus passes for traveling to school. Another reason these same students considered school X a healthy school was the importance given to physical activity and the time allotted for phys ed: "Outings at the end of the year weren't about going to the movies; they were about camp or activities that got us moving" or "We have phys ed almost every day; there's maybe only one day a week when there's no phys ed."

\subsubsection{Educators' Perspective}

Regarding the question of whether school $\mathrm{X}$ is a healthy school, we found it interesting that this group of adults discussed the issue of safety at length. The educators, like the students, emphasized schoolyard supervision, which serves to reduce conflicts and fights: "During recess periods, they have to register for a game, it's organized...the students aren't free" or "There are more pairs of eyes...So supervisors can intervene pretty quickly, before a situation deteriorates."

The educators also discussed physical activity: "I know that when there are sports for the whole school, they [phys ed teachers] promote them a lot." For this same group of adults, sports and safety are inseparable: "For 
example, to go to the soccer field a few streets away, it's obvious just by the way they walk in a line. And when they're on bikes, $[\ldots]$ the helmet's a must."

As for the second objective, examining educators' involvement in terms of health as perceived by the two groups, the focus group participants underscored the points below. Note that the findings are presented based on the four mechanisms in the model by Hoover-Dempsey et al. (2010), that is, modeling, reinforcement, teaching and encouragement.

\subsection{Educators' Involvement}

\subsubsection{Students' Perspective}

To the question "In school, what actions do your teachers take that convince you they consider your health important?", the students stressed teaching and encouragement especially, with a slight emphasis on modeling (Hoover-Dempsey et al., 2010). Emphasizing teaching first, the cycle 2 group specifies that educators want to teach them many things about health in general: "So we'll know more when we're older." And concerning lifestyles: "Our phys ed teachers give us pages to write down the bad habits we have to try to change, and the things to do for our health." As regards nutrition in particular: "They show us the four food groups and don't let us eat food that's not good for our health. "Students highlight the aspects of personal challenge and innovation relative to encouragement, for example, the cardiac stress test known as the shuttle test, which motivates them to improve their running time: "There's something else on the test with the beep that encourages us to do that. It's our record, 11 minutes; we have to try to beat it." They also mention the aspect of novelty for the same reasons: "I like to try new things; in phys ed it was the first time I ever saw those things, diabolos and poi [small materials used in performance art]."

Cycle 3 students point to various forms of reinforcement: "Whenever we have a healthy snack, like an apple or a vegetable, they [the teachers] give us a ticket, and then we have the chance to win a prize." From a more critical stance, however, the students in this group feel they are not given enough support for an active lifestyle: "It would be better to have two recess periods a day" to which another adds "To run more often." Furthermore, they see educators' involvement as a form of modeling: "The teachers join us, it's fun to try to do what they do" and "We go bike riding with the physical educators and they lead the way."

\subsubsection{Educateurs' Perspective}

To the question, "As educators, what actions do you take to empower your students in terms of their health?", participants discussed the four actions outlined by Hoover-Dempsey et al. (2010). The educators work towards a healthy school by privileging encouragement and teaching (Hoover-Dempsey et al., 2010). A few examples are as follows: "When they [the students] return after the weekend... I try to validate their outdoor activities, then I congratulate them a lot. I pay special attention to those who went outdoors. I've had my students for two years, I don't have many who play Nintendo or Playstation. They're proud to tell me they spent time outside." As well, the educators say that large-scale projects such as Mix-O-Fruit, Cross-country, the Athletics Challenge, the Winter Carnival and the Christmas Circus are ways to encourage healthy eating habits and an active lifestyle. Other actions target particular cycles and arouse students' interest: "They know that once they get to cycle 3, there'll be a five-hour ride in a Rabaska [a large canoe]; they'll get to spend a whole day on the river. Another time, we'll go for a bike ride in the National Park. This means there are special challenges in cycle 3, and the students are in a hurry for this!"

Regarding the information obtained, there was this example: "My students know the name of the four food groups [...]; they used to tell me what they ate for breakfast in the morning, for example. "I ate only two food groups." The educators specify that they regularly conduct learning activities that integrate general notions of health. They even offer advice to students that the latter can, in turn, convey to their parents.

Educators use reinforcement to a lesser extent, notably by rewarding students who bring healthy snacks by offering tickets for various prizes. A few insist on the importance of modeling as regards physical education and nutrition: "We have to be a bit like models, get into shape...there are bikes here, we [the teachers] use them" or "The students know that we eat healthy snacks too."

\section{Discussion}

The objectives of the present study were to 1) describe the perceptions of students and educators regarding school health, and 2) examine involvement based on the educators' actions to promote health as perceived by both groups of participants. The following section discusses the perspectives of these two groups toward the Healthy School Approach in a low-income environment. 


\subsection{School Health: Different Perceptions of Students and Educators}

First, it must be noted that all participants agree that school X is a healthy school. Their comments include some common denominators, since three variables of the Healthy School Approach model (Martin \& Arcand, 2005) were discussed in all the groups. These are: social skills, physical activities, and safe and healthy behaviours during travel and sports practices.

Social skills were examined in terms of school safety and discovered to be a common concern for all participants. In fact, the issue of safety raised in all the focus groups relates, essentially, to the infrastructures and teaching supervision aimed at ensuring good order. Students discussed safety in terms of the obligations and restrictions imposed by the school. Educators, for their part, stressed the effectiveness of supervision in the schoolyard and during outdoor excursions thanks to effective organization, well-defined roles, and a behaviour management system and means of intervention that were properly implemented. The importance of safety-related social skills leads us to conclude that the school carried out a number of mechanisms to ensure and promote school safety. Is there a reason for the Agir autrement intervention strategy in this disadvantaged school? Without a doubt. In Quebec, this strategy is the preferred method for preventing violence in disadvantaged environments (Dionne, Lavoie, Morency, \& Paradis, 2009; MEQ, 2009).

In addition to safety, the participants were thorough in discussing the practice of diverse physical activities. Cycle 3 students stand out in their awareness of the educational and promotional aspects conveyed by the educators; indeed, they show an understanding of their teachers' efforts to promote physical activity. We conclude that cycle 3 students, as opposed to those in cycle 2, can relate to the health component of education because of their greater maturity. In addition to the comments by Loizon (2009) recommending the meaningfulness and coherence of knowledge about health, it's important that those involved in health education take into account students' level of maturity and development.

Students discussed safe and healthy behaviours during travel and sports practices (such as the mandatory wearing of a bike helmet) in terms of obligations and restrictions, whereas educators underscored the preventive dimension. There is reason to believe, as suggested by Farley (2001), that these efforts by the school may reduce the difficulty of promoting bicycle safety in disadvantaged families.

On the other hand, some comments regarding the variables in the model (Martin \& Arcand 2005) were voiced by particular groups of participants. Why is it that the educators fail to mention nutrition when given the opportunity to express their views on the concept of school health? Are problems related to social skills a cause of such concern that this issue becomes the central focus? Are we to understand that educators have not grasped the importance of the various aspects of health in general? If so, then opportunities for exchange must be planned to help them develop a more holistic view of health, one that takes both individual and environmental factors into account (Martin \& Arcand 2005). These findings highlight the importance of a shared - but especially larger — vision that is in genuine alignment with a Healthy School approach.

\subsection{Educators' Involvement: Different Perspectives of Students and Educators}

Consistent with the typology of actions outlined by Hoover-Dempsey et al. (2010), educators are involved in the health of their students. Some forms of encouragement are described as follows. The students comment that educators encourage them, notably, to engage in more physical activity during recess or at home by setting up challenges. They [the students] appear to appreciate challenges, a fact linked to motivation, moreover, and well documented in the literature (e.g., Ryan, Lynch, Vansteenkiste, \& Deci 2011). Indeed, the educators recommend encouragement as a good strategy for motivating young people to practice physical activities, both inside and outside the school. They also associate their health education efforts with the school's success plan. According to Arcand (1998) and Deschesnes and Lefort (2004), the school's health-based success plan constitutes, effectively, the point of departure for promoting concerted actions for health education. It is the central training element for the school staff as a whole. The interviewed educators believe they have a role and mandate to get students moving by means of multiple physical and educational activities, all of which form the basis of a subject area that focuses on health and figures in their success plan.

The students also discussed teaching, as they feel this has given them new information about health and lifestyles. They stress the contribution of active homework and the assumption of responsibility for their lifestyle with the particular aid of supervision by phys ed teachers. We believe this fosters an open teaching context that is conducive to a greater autonomy and reasoning capacity in the young. The educators' emphasis on teaching comes as no surprise considering they are charged with the educational mission of the Quebec school. But how compatible are their actions and contents with the Québec Education Program, which is one of the criteria for 
the effectiveness of school initiatives (Roberge \& Choinière, 2009)? Here is the basis for an entirely new and relevant avenue of research.

Although the participants focus less on reinforcement, the students recognize that healthy snacks rewarded by chances to win a prize are a good way to improve their eating habits. The educators share this opinion as well, since they point to their habit of offering rewards to the most deserving.

Students state that educators provide an example by participating in the different physcial activities available in the school. Similarly, the educators view themselves as models having a certain obligation to join in student activities, as this is likely to impact young people's behaviours and attitudes. Furthermore, is it possible that young people can, in turn, influence their parents? The educators continue to rely on this transfer to the family, since they view the students, correctly, as potential messengers. We find it would be interesting, within the context of interventions and continuing studies, to explore the role of the student as an agent of change within the family. Could not students be enlisted to further health education in their families? These few avenues are part of the search for concerted and complementary efforts in health education, particularly in low socioeconomic environments.

\section{Conclusion}

The data depict a school committed to health despite its disadvantaged status. The success plan served as an anchorage point for implementing school activities with the collaboration of the school staff. The educators, already sensitized to the importance of health education, are in a position to propose various activities and support their students' efforts, at least in the view of the participants interviewed. Martin and Arcand (2005), moreover, stess that the mobilization of the school staff is an essential element in the implementation of health education strategies in the school. Although the literature makes little mention of this issue as regards students, the present study supports the student's undeniable role while examining it more closely in terms of the future.

All in all, our study describes real actions taken to promote health and allows us to anticipate a continuity despite the school's disadvantaged status. New conceptions of health education are presently emerging in Quebec. Health education in the school, as supported by the Healthy School Approach, can be seen as a societal project bringing together various actors to further the goal of every health education initative, which is the health and well-being of our young people.

\section{Acknowledgements}

The authors wish to express their thanks to Virginie Roy, student at the Universite du Quebec a Trois-Rivieres for her work analyzing the data.

\section{References}

Bandura, A. (1997). Self-efficacy. The exercise of control. NY: W. H. Freeman and Company.

Baltasar, A., Feller-Lânzlinger, R., Furrer, C., \& Biebricher, M. (2007). Évaluation de l'efficacité du Réseau Suisse d'Écoles en santé [Evaluation of the effectiveness of the Schools Health Network Switzerland]. Résumé du rapport final. Sur mandat de Promotion Santé Suisse et de l’Office Fédéral de la santé publique. Retrieved from http://upload.sitesystem.ch/B2DBB48B7E/5B4613A676/77244D52CE.pdf

Beaudoin, C. (2011). Twenty years of Comprehensive School Health: A Review and Analysis of Canadian Research Published in Refereed Journals (1989-2009). PHENex Journal, 3(1), 1-17.

Bogdan, R. C., \& Biklen, S. K. (1992). Qualitative research for education. An introduction to theory and methods. Toronto, Canada: Allyn and Bacon.

Bronfenbrenner, U. (1986). Ecology of the family as a context for human development: Research perspectives. Developmental Psychology, 22, 723-742.

Deniger, M.-A., Abdoulaye, A., Dubé, S., \& Goulet, S. (2009). Les représentations du système scolaire des familles issues de milieux défavorisés [Representations of the school system for families from disadvantaged backgrounds]. Retrieved from http://www.crires-oirs.ulaval.ca/webdav/site/oirs/... /Rapport-Final-03-2010.pdf

Deschesnes, M., Couturier, Y., Laberge, S., Trudeau, F., Kébé, M., Campeau, L., ... Bertrand, M. (2008). Les facteurs influençant la dissémination et l'adoption de l'approche École en santé [Factors influencing the dissemination and adoption of the Healthy School approach]. Québec, Québec : Gouvernement du Québec, Institut national de santé publique. 
Deschesnes M., Martin, C., \& Jomphe-Hill, A. (2003). Comprehensive approaches to school health promotion: how to achieve broader implementation? Health Promotion International, 18(4), 387-396. http://dx.doi.org/10.1093/heapro/dag410.

Deslandes, R. (2010). Crucial conditions for successful school-family-community partnerships. Retrieved from http://www.coeureaction.qc.ca/en/crucial-conditions.aspx

Dionne, F., Lavoie, M., Morency, S., \& Paradis, F. (2009). Perceptions du milieu scolaire concernant l'animation et l'aménagement des cours d'école au primaire dans la région de la Capitale-Nationale [Perceptions of the school environment regarding the animation and the design of school playgrounds in the region of the Capitale-Nationale]. Québec, Québec: Agence de la santé et des services sociaux de la Capitale-Nationale, Direction régionale de santé publique.

Farley, C. (2001). Le vélo en toute sécurité. Mais comment? [The bike safely. But how?]. La santé de l'homme, $354,48-49$.

Geoffrion, P. (2003). Le groupe de discussion [Then focus group]. In B. Gauthier. (Dir.), Recherche sociale. De la problématique à la collecte de données (pp. 333-356). Québec, Sainte-Foy : Presses de l'Université du Québec.

Grenier, J., Otis, J., \& Harvey, G. (2010). Faire équipe pour l'éducation à la santé en milieu Scolaire [To make a team for health education in schools]. Coll. Santé et Société. Québec, Québec: Presses de l'Université du Québec.

Harris A., \& Goodall, J. (2007). Engaging parents in raising achievement. Do parents know they matter? Research Report DCSF-RW004. Coventry UK: University of Warwick. Retrieved from http://www.dcsf.gov.uk/research/data/uploadfiles/DCSF-RW004.pdf

Hoover-Dempsey, K. V, Whitaker, M. C., \& Ice, C. L. (2010). Motivation and commitment to family-school partnerships. In S. L. Christenson, \& A. L Reschly (Eds.), Handbook of School-Family Partnerships (pp. 30-60). New York, NY: Routledge.

Jourdan, D. (2010). Éducation à la santé. Quelle formation pour les enseignants [Health education: what training for teachers?]. Coll. Santé en action. Saint-Denis, France : Éditions INPES.

Kitzinger, J., \& Barbour, R. S. (1999). Developing focus group research. Politics, theory and practice. Thousand Oaks, CA: Sage Publications.

L'Écuyer, R. (1990). Méthodologie de l'analyse développementale de contenu. Méthode GPS et concept de soi [Methodology of the analysis of developmental content. GPS method and self-concept]. Québec, Québec: Presses de l'Université du Québec.

Larose, F., Lenoir, Y., \& Karsenti, T. (2002). À quoi peuvent bien servir les TIC en enseignement? [What can serve ICT teaching?]. In F. Larose, \& T. Karsenti (Dir.), La place des TIC en formation initiale et continue: Bilan et perspectives (pp. 20-40). Sherbrooke: Éditions du CRP.

Loizon, D. (2009). Éducation à la santé: Quels savoirs enseignés en ÉPS à l'IUFM? [Health education: what knowledge taught in PHE in IUFM?]. Revue ÉPS, 1(141), 27-29.

Lynagh, M., Perkins, J., \& Schofield, M. (2002). An evidence-based approach to health promoting schools. Journal of School Health, 72(7), 300-302. http://dx.doi.org/10.1111/j.1746-1561.2002.tb01337.x

Martin, C., \& Arcand, L. (2005). Guide à l'intention du milieu scolaire et de ses partenaires. Pour la réussite éducative, la santé et le bien-être des jeunes [Guide for the school and its partners. For educational success, health and well-being of youngsters]. Québec, Québec: Gouvernement du Québec, Ministère de l'Éducation, du Loisir et du Sport.

Merriam, S. B. (1998). Qualitative research and case study applications in education (2nd ed.). San Francisco: Jossey-Bass.

Ministère de l'Éducation du Québec. (1997). Réaffirmer l'école. Prendre le virage du succès. Rapport du groupe de travail sur la réforme du curriculum [Reaffirm the school. Turning the Corner success. Report of the Task Force on Curriculum Reform]. Québec, Québec : Gouvernement du Québec.

Ministère de l'Éducation du Québec. (2001). Programme de formation de l'école québécoise: éducation préscolaire, enseignement primaire [Curriculum Quebec schools: preschool, primary]. Québec, Québec: Gouvernement du Québec. 
Ministère de l'Éducation du Québec. (2002). Les services éducatifs complémentaires: essentiels à la réussite [Complementary Educational Services: Essential to Success]. Québec, Québec : Gouvernement du Québec.

Ministère de l'éducation du Québec. (2003). Bulletin statistique de l'éducation. La carte de la population scolaire et les indices de défavorisation [Statistical bulletin of education. Map of the school population and disadvantaged indices]. Québec, Québec : Gouvernement du Québec.

Ministère de l'Éducation, du Loisir et du Sport. (2004). Programme de formation de l'école québécoise: enseignement secondaire, $1^{e r}$ cycle [Curriculum Quebec schools: secondary, first cycle]. Québec, Québec: Gouvernement du Québec.

Ministère de l'Éducation, du Loisir et du Sport. (2009). La violence à l'école : ça vaut le coup d'agir esnemble! [Violence in schools: it's worth to act together]. Plan d'action pour prévenir et traiter la violence à l'école 2008-2011. Québec, Québec : Gouvernement du Québec.

Mo, F., Turner, M., Krewski, D., \& Mo, F. D. (2005). Physical inactivity and socioeconomic status in Canadian adolescents. International Journal of Adolescent Medicine and Health, 17(1), 49-56. http://dx.doi.org/10.1515/IJAMH.2005.17.1.499

Otis, J. (2009). L'éducation à la santé en milieu scolaire: d'hier à aujourd'hui [Education for School Health: Then and now]. Formation et profession, 16(2), 7-14.

Patton, M. Q. (2002). Qualitative Research and Evaluation Methods. Thousand Oaks, CA: SAGE Publications.

Puhse, U., \& Gerber, M. (2005). An International comparison of physical education: concepts, problems, prospects. Oxford, Londres: Meyer \& Meyer Sport.

Rissel, C., \& Rowling, L. (2000). Intersectoral collaboration for the development of a national framework for health promoting schools in Australia. Journal of School Health, 70(6), 248-250. http://dx.doi.org/10.1111/j.1746-1561.2000.tb07429.x

Rivard, M.-C., \& Beaudoin, C. (2009). Les visages multiples de l'éducation à la santé en milieu scolaire [The many portraits of health education in schools]. Bulletin Formation et Profession, 16(2), 29-33.

Rivard, M.-C., \& Deslandes, R. (2012). Engagement of educators and parents in students' health education in a low socioeconomic school in Quebec: A case study. Health Education Journal, 72(5), 537-544. http://dx.doi.org/10.1177/0017896912450903

Rivard, M.-C, Deslandes, R., \& Beaudoin, C. (2011). Collaboration within the context of the Healthy School Approach (HSA): The case of a disadvantaged elementary school in Quebec. Canadian Journal of Education, 34(4), 158-176.

Rivard, M.-C., Porlier, P., \& Collet, M. (2009). Les pratiques évaluatives au $1^{\text {er }}$ cycle du secondaire : Tendances en éducation physique et à la santé [Evaluation practices in Secondary first cycle : Trends in physical education and health]. Rapport de recherche. Québec: Université du Québec à Trois-Rivières et Ministère de l'Éducation, du Loisir et du Sport.

Roberge, M.-C., \& Choinière, C. (2009). Analyse des interventions de promotion de la santé et de prévention en contexte scolaire québécois: Cohérence avec les meilleures pratiques selon l'approche École en santé [Analysis of interventions to promote health and prevention Quebec school context consistent with the best practices in the Healthy Schools approach]. Québec, Québec: Gouvernement du Québec, Institut national de santé publique.

Ryan, R. M., Lynch, M. F., Vansteenkiste, M., \& Deci, E. L. (2011). Motivation and autonomy in counseling, psychotherapy, and behavior change: A look at theory and practice. The Counseling Psychologist, 39, 193-260. http://dx.doi.org/10.1177/0011000009359313

St Leger, L., \& Nutbeam, D. (2000). Finding common ground between health and education agencies to improve school health: Mapping goals, objectives, strategies, and inputs. Journal of School Health, 70(2), 45-50. http://dx.doi.org/ 10.1111/j.1746-1561.2000.tb07239.x

Skinner, B.F. (1989). Recent issues in the analysis of behavior. Columbus, OH: Merrill Publications.

Stalsberg, R., \& Pedersen, A.V. (2010). Effects of socioeconomic status on the physical activity in adolescents: A systematic review of the evidence. Scandinavian Journal of Medicine \& Science in Sports, 20(3), 368-383. http://dx.doi.org/10.1111/j.1600-0838.2009.01047.x 
Turcotte, S., Gaudreau, L., \& Otis, J. (2007). Les objets d'enseignement-apprentissage: éléments d'illustration de l'inclusion de l'éducation à la santé en éducation physique [The teaching-learning objects: elements illustration of the inclusion of health education in physical education]. Revue STAPS, 75, 115-129.

World Health Organization. (1986). The Ottawa Charter for Health Promotion. Retrieved September 2009 from http://www.who.int/healthpromotion/conferences/previous/ottawa/en/

World Health Organization. (1997). Jakarta Declaration on Leading Health Promotion into the 21st Century. Retrieved from http://www.who.int/healthpromotion/conferences/previous/jakarta/declaration/en/

Yin, R. K. (2003). Case study research. Design and methods (3th ed.). Thousand Oaks, CA: Sage Publications.

\section{Note}

Note 1. In Québec, a socioeconomic environment index (EEI) is calculated by the Ministry of Education (2003). A third of the EEI calculated represents the proportion of parents who are unemployed, while two-thirds correspond to the proportion of mothers who did not graduate from high school.

\section{Copyrights}

Copyright for this article is retained by the author(s), with first publication rights granted to the journal.

This is an open-access article distributed under the terms and conditions of the Creative Commons Attribution license (http://creativecommons.org/licenses/by/3.0/). 